\title{
Application of Remote Sensing and Developed Allometric Models for Estimating Wood Carbon Stocks in a North-Western Miombo Woodland Landscape of Tanzania
}

\author{
Geofrey Soka ${ }^{1}$ and Nanjiva Nzunda ${ }^{2}$ \\ ${ }^{1}$ Department of Wildlife Management, Sokoine University of Agriculture, P.O. Box 3073, Morogoro, Tanzania \\ ${ }^{2}$ Department of Forest Biology, Sokoine University of Agriculture, P.O. Box 3000, Morogoro, Tanzania \\ Correspondence should be addressed to Geofrey Soka; gesoka@gmail.com
}

Received 31 December 2013; Revised 31 March 2014; Accepted 3 May 2014; Published 5 June 2014

Academic Editor: Henry M. Page

Copyright ( $) 2014$ G. Soka and N. Nzunda. This is an open access article distributed under the Creative Commons Attribution License, which permits unrestricted use, distribution, and reproduction in any medium, provided the original work is properly cited.

\begin{abstract}
Quantifying ecosystem carbon stocks is vital for understanding the relationship between changes in land use and cover (LULC) and carbon emissions; however, few studies have documented the impacts of carbon cycling on Miombo ecosystems. Here, we estimate the amounts of wood carbon which is stored and lost as a result of LULC changes in Kagoma Forest Reserve (KFR) for the periods between 1988 and 2010 using GIS data, Landsat imagery, and field observations. The land cover was captured on the basis of Landsat 5 TM and Landsat 7 ETM. The amounts of wood carbon stored and lost were estimated based on four previously developed allometric models. Spatial analysis of the Landsat images shows that in the year 1988, woodlands dominated the area by covering $32.66 \%$ whereas in the year 2010 the woodlands covered only $7.34 \%$ of the total area. The findings of the current study reveal that KFR had undergone notable changes in terms of LULC for the period of 1988-2010. It was estimated that the woodlands in the KFR lost an average of $4409.79 \mathrm{t} \mathrm{Cyr}^{-1}$. In this study, the amount of carbon stocks stored was estimated to be 21457.02 tonnes in tree stem biomass based on the area (1226.12 ha) that was covered by woodlands. We estimated that an average of $17.79 \mathrm{t} \mathrm{Ch}^{-1}$ was stored in the Miombo woodlands based on the four models. The efforts to ensure sustainable management of the Miombo ecosystem can contribute to the creation of a considerable carbon sink.
\end{abstract}

\section{Introduction}

Miombo woodlands are widespread in the tropics, covering over $2.7 \times 10^{3} \mathrm{~km}^{2}$ in east, central, and southern Africa [1]. It occurs on poor soils derived from acid crystalline bedrock occurring under a hot, seasonally wet climate [2]. Its woody vegetation is mainly dominated by Brachystegia spp., Julbernardia spp., and Isoberlinia spp. [1]. Miombo woodlands ecosystems are considered to directly support the livelihood of an estimated 39 million people, particularly in low income rural communities in central African countries [1, 2]. The woodlands supply charcoal, firewood, fruits, building poles, and timber to over 15 million people living in the urban areas in the region [1]. Woody biomass consumption from Miombo woodland is said to amount to about $48 \mathrm{Tg} \mathrm{yr}^{-1}$, releasing almost $22 \mathrm{Tg}$ of Carbon to the atmosphere [2].
For example in Tanzania, forests and woodlands cover more than $40 \%$ of the total land surface and directly support the livelihood of over $85 \%$ of the rural poor [3].

Cultivation and deforestation mainly for charcoal production have been reported to be the major factors that contribute to the decline of Miombo woodlands [4]. Considering the fact that up to $50 \%$ of rural poor income in some areas is dependent on the woodlands, degradation of these woodlands could result into a huge economic and social crisis $[4,5]$. The potential of the woodlands to act as a carbon sink and to provide other essential ecosystem services has also been compromised [5]. The expansion of cultivation in many parts of the world has transformed the land cover from natural vegetation to more agroecosystems $[6,7]$. These changes have been fuelled by a growing demand for agricultural products that are important for improving 
food security and generating income not only for the rural poor but also for the large-scale investors in the commercial farming sector. Natural vegetation cover has given way not only to cropland but also to native or planted pasture [8]. Also, considerable importance to LULC change in East Africa is the expansion of urban centres. Globally, concerns about the changes in land use/cover emerged due to the realization that land surface processes have an influence on the climate and that changes in these processes have an impact on the ecosystem goods and services [8]. The impacts which have been of primary concern are the negative effects of LULC change on biological diversity, soil degradation, and the ability of biological systems to support human needs. Increasing levels of $\mathrm{CO}_{2}$ in the atmosphere can be linked to global climate changes [9]. These changes have made the world more vulnerable to the rising of sea levels [10], desertification, and biodiversity losses in different ecosystems in the world [11].

Anthropogenic alterations of the natural landscape through urbanization, agriculture, and forestry have been continuous and increasing for the past millennium [12]. Areas of the natural vegetation and land cover are removed and replaced with the human managed systems of altered structure [13]. During the last century, land use has changed drastically in the tropics due to changing economy and growing population [14]. This has caused significant and adverse effects on physical and ecological process [15], on soil and water [16], on local and global climate, and on biodiversity [17]. A study by Meyer and Turner [18] shows that land use deliberately alters land cover such as vegetation by changing this land cover into a different state such as building materials, medicinal, wood, and fuel, hence deforestation. Recently, efforts have been made to quantify the nature and extent of LULC changes including vegetation at global scale [19-21]. Richards [22] estimated that, over the last 300 years, the total global area of forest and woodland diminished by $19 \%$, while grasslands increased by $46.6 \%$. Despite the recognition on the magnitude and impact of global changes in LULC, there have been relatively few comprehensive studies on land use changes and their impacts [23]. For example, Kaoneka [24] reported declining area of natural forest reserve in the Usambara Mountains at a fairly high rate of 3.8\% per year.

There have been research efforts to quantify carbon stocks in Tanzania focusing on the tropical montane forests $[5,25]$ which are known to store large amounts of carbon. Despite that useful comparatively studies have been undertaken in Zambia, Malawi, Mozambique, and Zimbabwe, much less attention has been paid to the Miombo woodlands in Tanzania [1, 26-28]. Miombo woodland vegetation is assumed to contain less carbon than the montane forests due to their structural nature [25]. The coverage of miombo woodland vegetation in terms of area is, however, large and may comprise a significant part of the total carbon storage potential of Tanzania. This potential is yet to be fully evaluated and the carbon storage of Tanzanian miombo woodland remains a significant knowledge gap. A key aspect of determining the carbon benefit of any forest carbon project is to accurately quantify the levels of carbon changes [5]. The analysis of the potential of the Miombo woodland ecosystems to store carbon is a key to understanding whether the corrective measures taken in LULC changes and forest management are likely to create net carbon sources or sinks. Such estimates are important in designing management plans for the Miombo woodlands that may ensure a sustained potential of this ecosystem's contribution to the mitigation of emission [5].

Sustainable utilization of forest resources including maintenance of high amounts of standing biomass, reduction of deforestation, and reafforestation of marginal agricultural lands is crucial. This will offer possibilities of reducing global warming and maintaining local and regional ecological systems [29]. Recently, the United Nations Framework Convention on Climate Change (UNFCCC) has initiated discussions on the mechanisms to reduce emissions from deforestation and degradation (REDD) in developing countries. The REDD concept proposed to provide financial incentives to help developing countries facilitate and enforce voluntary reduction of national deforestation and associated carbon emissions below a baseline. If properly executed, the reduction of emissions could simultaneously combat climate change, conserve biodiversity, and protect other ecosystem goods and services [29].

The knowledge about the current condition and the extent of forest cover as well as the amount of carbon stored in these forests are necessary. It is also important to know the amount of carbon stocks lost as a result of LULC changes in the Miombo woodlands. The main carbon sinks in the tropical forest ecosystems are the living biomass of trees [29]. The carbon stored in the above-ground living biomass of trees typically constitutes the largest pool and is the most directly impacted by deforestation and degradation [30]. Estimating the above-ground forest biomass is therefore one of the most critical steps in quantifying carbon stocks and fluxes from tropical forests. Little is known about carbon stocks stored and lost as a result of LULC dynamics in the KFR. Quantifying ecosystem carbon stocks is vital for understanding the relationship between changes in LULC and carbon emissions [31]; however, few studies have documented the impacts of carbon cycling on Miombo ecosystems. Here, we estimate the amount of carbon stocks stored and lost as a result of land use dynamics in the KFR for the periods between 1988 and 2010 using field observations, GIS data, and Landsat imagery.

\section{Materials and Methods}

2.1. Description and Location of the Study Area. KFR is found in Bukoba Rural District, Kagera Region in Tanzania (Figure 1), and lies within longitudes $1^{\circ} 29^{\prime} 49^{\prime \prime} \mathrm{S}-$ $1^{\circ} 39^{\prime} 18^{\prime \prime} \mathrm{S}$ and latitudes $31^{\circ} 18^{\prime} 27^{\prime \prime} \mathrm{E}-31^{\circ} 19^{\prime} 20^{\prime \prime} \mathrm{E}$. The forest has $16,697.92$ ha and is about $1245 \mathrm{~m}$ above the sea level. Bukoba Rural District is one of the six districts of the Kagera Region occupied by different tribes, but mainly the Haya tribe. The geographical coverage of the district is $5282 \mathrm{~km}^{2}$ of land and $7925 \mathrm{~km}^{2}$ of water and mostly Lake Victoria, including more than 20 islands in the Lake. Major landforms are hills and ridges with a north-south orientation, valleys, uplands, and plains. Soil types vary according to location, and the 


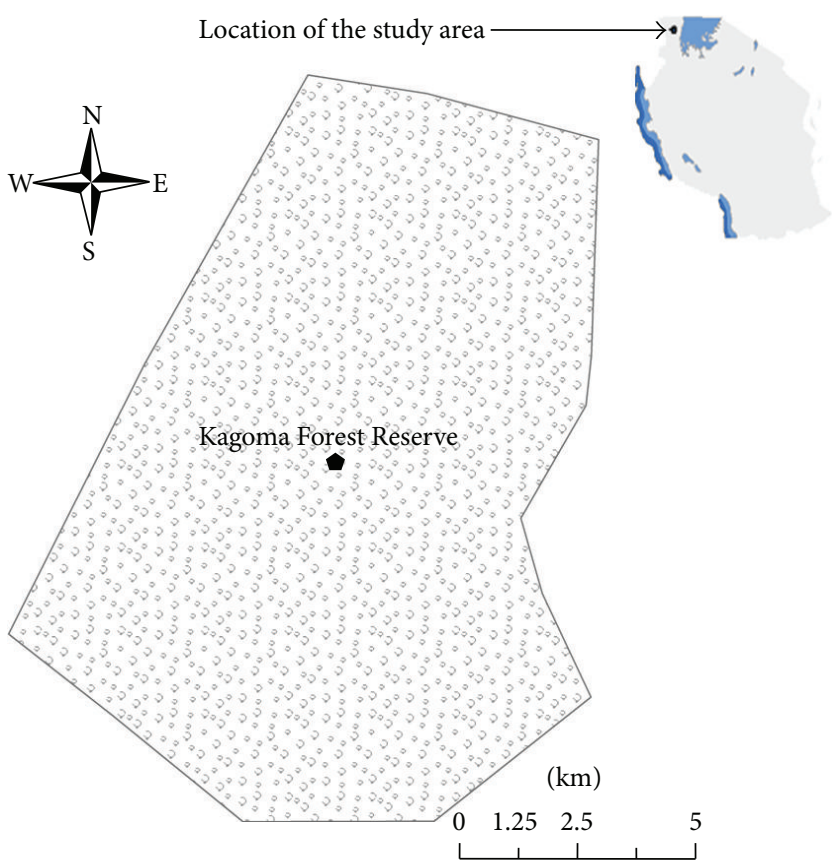

FIGURE 1: A map of study area. The inset map (upper right) shows the location of Kagoma Forest Reserve in Tanzania.

common ones are described by Touber and Kanani [32] as Ferralsols, Fluvisols, Arenosols, and Gleysols. Rainfall is very much influenced by topography and the presence of Lake Victoria. A rather steep gradient in the total annual rainfall is observed from $2100 \mathrm{~mm}$ along the coast to less than $700 \mathrm{~mm}$ towards the interior [32]. The average daily temperatures are relatively low and fluctuate between $15^{\circ} \mathrm{C}$ and $28^{\circ} \mathrm{C}$, with an average of $20^{\circ} \mathrm{C}$ [33]. KFR hosts different wildlife species such as elephants (Loxodonta Africana), whereby a large group of 200 elephants which shifted from neighbouring Game Reserves of Burigi and Ibanda Rumanyika due to habitat fragmentations have moved to the KFR for refuge. The KFR also hosts Impala (Aepyceros melampus), waterbuck (Kobus ellipsiprymnus), roan antelope (Hippotragus equinus), birds, and other wildlife species [33]. There is a large stand of Miombo woodlands and the site is rich in tree species of conservation importance including African Blackwood (Dalbergia melanoxylon), Mvule (Milicia excelsa), and Muninga (Pterocarpus angolensis) thickets.

2.2. Analysis of LULC Changes. Remote sensing is an effective tool for quantifying the impacts of LULC on forest ecosystems at landscape scales. The materials used in the study were Landsat 5 TM of 5th June, 1988, and Landsat 7 ETM+ of 5th June, 2010. Topographical maps with a scale of $1: 50,000$ were used for georeferencing Landsat scenes. Global positioning system (GPS) was used in LULC map verification and updating LULC map to include land use pattern up to year 2010. The images were selected based on seasonality of the imageries, spatial resolution $30 \mathrm{~m}$, study location, and availability of imageries. The LULC was captured on the basis of Landsat 5 TM p172r061 scene of August, 1988, and Landsat7 Enhanced
Thematic Mapper Plus (ETM+) p172r061 of June, 2010. The imageries were obtained from archive of the Geo-Network Limited, Dar es Salaam Tanzania, and Sokoine University of Agriculture GIS Laboratory. Topographical sheets with a scale of 1:50,000 of 1967 were acquired from the Surveys and Mapping Division of the Ministry of Lands, Housing and Human Settlements Development for georeferencing Landsat images and during the preparation of LULC interpretation key. The land cover maps produced by Africover project in 1995 were also obtained from the Institute of Resource assessment (IRA) of the University of Dar es Salaam. These land use maps were used as base maps during LULC interpretation.

2.3. Preprocessing of Landsat Data. The 2010 image was georeferenced using ERDAS IMAGINE 9.1 Software with reference to topographical map of a scale of 1:50000 of the study site. Easily identifiable ground control points on permanent features were used. Thus, image coordinates were transformed into map coordinates as per 36 Universal Transverse Mercator (UTM) zone, projected to UTM, spheroid Clark 1880, and Datum Arc 1960. The 1988 image was georeferenced using the already georeferenced 2010 image. Two rectified images were reduced to the size of the study site by using subset command in ERDAS imagine software.

\subsection{Ground Truthing and Interpretation of Landsat Images.} Land use types identified from the image scenes of 1988 and 2010 were counter-checked by carrying out fieldwork in the study area in order to update data interpreted from the images. Ground coordinates for different land cover types were recorded by using GPS. The recorded coordinates were then used to transform former LULC types before performing LULC change detection for generating the final results. The enhanced images in ERDAS IMAGINE 9.1 Software were converted to ArcGIS 9.3 for interpretation. The image analysis extension in ArcGIS 9.3 sharpened more features interest in the study area. Different land cover categories were extracted using photo texture. False colour composite was formed using red, green, and blue (RGB) for bands 4, 3, and 2. An onscreen digitization procedure was used in identifying land covers. The analysis of land cover in KFR was done in an area covering a total of 16663 hectares and the area was stretched to include a bigger area covering village land bordering the forest in order to relate human factors influencing land cover changes within the forest. The cover classes were determined based on ground truthing data which were used as reference points for each land cover recorded in the field.

\subsection{Land Use and Vegetation Cover Change Detection.} Change detection was performed through the overlay method based on generated vector themes of different years. Change detection was done between datasets of 1988 and 2010 years. The overlay was performed by intersecting feature themes so that the boundaries and attributes of themes were combined to form the derivative output theme. The attribute tables of the output themes were summarized in the definition tables and the results were exported in MS-Excel Package to 
TABLE 1: Selected allometric models from different Miombo ecosystems.

\begin{tabular}{ll}
\hline Equation & Source \\
\hline$B=0.0069 \mathrm{DBH}^{2.9756}$ & Munishi et al. [5] \\
$B=0.06 * D^{2.012} * \mathrm{Ht}^{0.71}$ & Malimbwi et al. [34] \\
$B=\operatorname{EXP}(-1.996+2.32 * \ln (D))$ & Brown [35] \\
$B=0.0625 D^{2.553}$ & Chamshama et al. [36] \\
\hline
\end{tabular}

Note: $B$ : biomass $(\mathrm{t}) ; D$ : diameter $(\mathrm{cm})$ at $1.3 \mathrm{~m}(\mathrm{DBH}), \mathrm{Ht}$ : tree height $(\mathrm{m})$.

compile areas of change for each information category. The change detection analysis entails finding the type, amount, and location of LULC changes that are taking place [37]. In this study, a postclassification comparison method was used to assess LULC changes. It is the most common approach for comparing data from different sources and dates [38]. The advantage of postclassification comparison is that it bypasses the difficulties associated with the analysis of images acquired at different times of the year and/or by different sensors [39]. The method has been found to be the most suitable for detecting land cover changes [40]. The only pitfall is that the accuracy of the change maps depends on the accuracy of individual classifications and is subject to error propagation $[40,41]$. The estimation for the rate of change for the different covers was computed based on the following formulae [42]:

$$
\begin{gathered}
\% \text { Cover change }=\frac{\text { Area }_{i \text { year } x}-\text { Area }_{i \text { year } x+1}}{\sum_{i=1}^{n} \operatorname{Area}_{i \text { year } x}} \times 100 \\
\text { Annual rate of change }=\frac{\text { Area }_{i \text { year } x}-\text { Area }_{i \text { year } x+1}}{t_{\text {year }}}
\end{gathered}
$$

$\%$ Annual rate of change

$$
=\frac{\operatorname{Area}_{i \text { year } x}-\text { Area }_{i \text { year } x+1}}{\operatorname{Area}_{i \text { year } x} \times t_{\text {years }}} \times 100,
$$

where $\operatorname{Area}_{i \text { year } x}=$ area of cover $i$ at the first date, Area $_{i \text { year } x+1}=$ area of cover $i$ at the second date, $\sum_{i=1}^{n}$ Area $_{i \text { year } x}=$ total cover area at the first, and $t_{\text {years }}=$ period in years between the first and second scene acquisition data

2.6. Estimation of the Tree Biomass and Carbon Stocks. Data on carbon stocks are reported using selected allometric models from different authors based on studies conducted in the Miombo ecosystems (Table 1). In order to determine tree biomass and carbon, four previously used allometric models developed for general tropical woodlands and Miombo savanna were used to estimate the biomass and carbon density. Tropical forests often contain 300 or more species, but research has shown that species-specific allometric relationships are not needed to generate reliable estimates of forest carbon stocks [29, 43]. Allometric equations can be used to estimate the biomass and carbon stock of forests [44, 45]. Generalized allometric equations have a major advantage of being based on larger numbers of trees that span a wider range of diameters $[29,43]$. The quantity of carbon for a

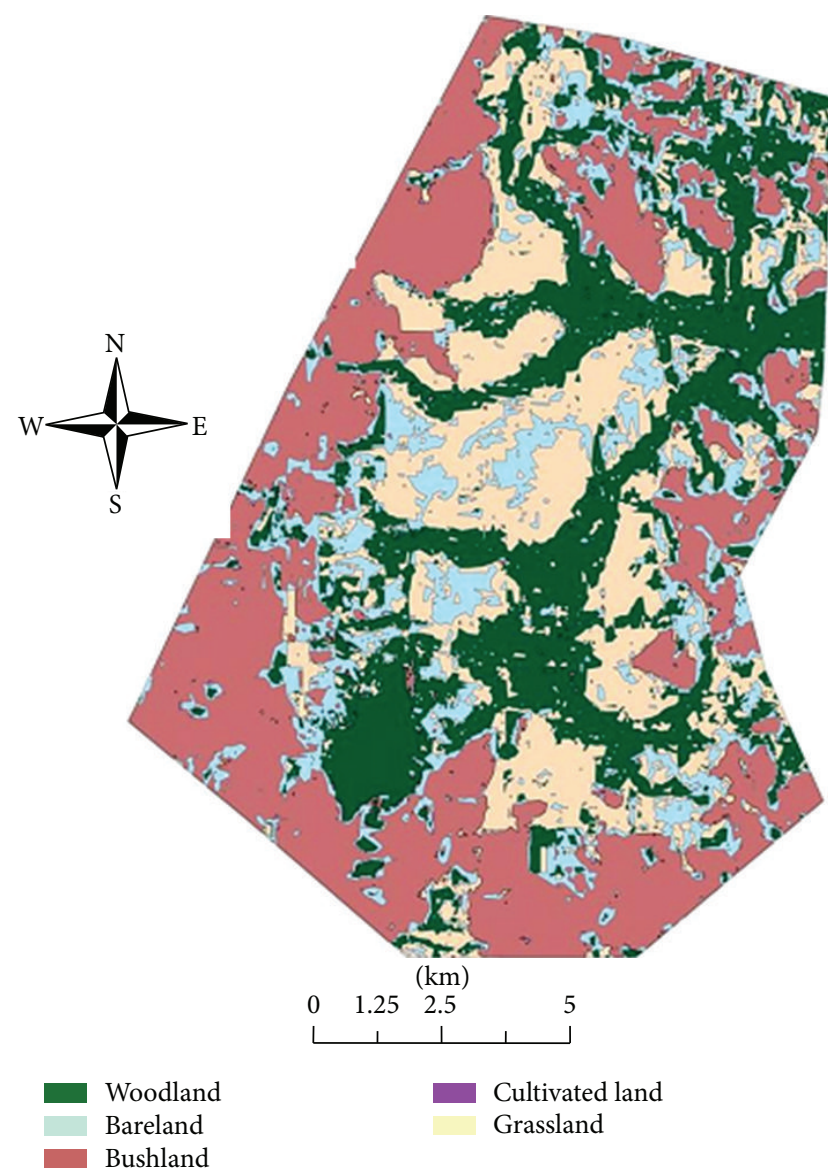

FIGURE 2: Land use and land cover map of image scene, 1988.

given wood biomass was estimated to be $50 \%$ of the total biomass $[25,46]$. Using the average carbon stock obtained in this study, the total C stored and total C lost in KFR were calculated by multiplying the carbon stock with the total area covered by woodlands from 1988 to 2012 .

\section{Results and Discussion}

3.1. Land Use and Land Cover Class Distribution. The land cover maps for 1988 and 2010 are presented in Figures 2 and 3 , respectively. Generally, the maps show the variation in cover between the two time periods under consideration. In year 1988, woodlands dominated the area by covering $32.66 \%$ (5453.37 ha) followed by bushland which covered $27.37 \%$ (4570.43 ha). Grassland covered 24.35\% (4065.50 ha), followed by bareland/settlements $15.46 \%$ ( $2581.10 \mathrm{ha})$, whereas the cultivated land occupied only $0.16 \%$ ( $27.53 \mathrm{ha})$.

Spatial analysis of the Landsat image shows that in year 2010, woodlands covered only $7.34 \%$ (1226.12 ha) of the total area as shown in Figure 3. Bushland increased in terms of coverage from previous $23.5 \%$ ( $3923.43 \mathrm{ha}$ ) to $32.25 \%$ (5385.9 ha) of the total area, followed by settlement area $25.11 \%$ (4193.32 ha), grassland covered 23.15\% (3865.39 ha), and cultivated land expanded to $12.14 \%$ (2027.20 ha). During this period (1988-2010), the results show a substantial 
TABLE 2: Cover area and the rate of change between 1988 and 2010.

\begin{tabular}{|c|c|c|c|c|c|c|c|c|}
\hline \multirow{2}{*}{ Cover class } & \multicolumn{2}{|c|}{ Land cover in 1988} & \multicolumn{2}{|c|}{ Land cover in 2010} & \multicolumn{4}{|c|}{ Changes over 22 years } \\
\hline & Area (ha) & $\begin{array}{l}\text { Percentage } \\
\text { of cover }\end{array}$ & Area (ha) & $\begin{array}{l}\text { Percentage } \\
\text { of cover }\end{array}$ & $\begin{array}{c}\text { Area } \\
\text { change } \\
\text { (ha) }\end{array}$ & $\begin{array}{c}\text { Percentage } \\
\text { of cover } \\
\text { change }\end{array}$ & $\begin{array}{l}\text { Annual rate of } \\
\text { change (ha/yr) }\end{array}$ & $\begin{array}{c}\% \text { Annual rate } \\
\text { of change (\%/yr) }\end{array}$ \\
\hline Woodland & 5453.37 & 32.66 & 1226.12 & 7.34 & -4227.25 & -25.32 & -192.15 & -1.15 \\
\hline Grassland & 4065.50 & 24.35 & 3865.39 & 23.15 & -200.11 & -1.20 & -9.10 & -0.05 \\
\hline Cultivated land & 27.53 & 0.16 & 2027.20 & 12.14 & 1999.67 & 11.98 & 90.89 & 0.54 \\
\hline Bushland & 4570.43 & 27.37 & 5385.90 & 32.25 & 815.47 & 4.88 & 37.07 & 0.22 \\
\hline Bareland/settlements & 2581.10 & 15.46 & 4193.32 & 25.11 & 1612.22 & 9.66 & 73.28 & 0.44 \\
\hline Total area & 16697.92 & 100.00 & 16697.92 & 100.00 & & & & \\
\hline
\end{tabular}

TABLE 3: Biomass and carbon stock estimates from four different modelsat KFR for 22 years.

\begin{tabular}{lcccc}
\hline Source & Estimated biomass $\left(\mathrm{t} \mathrm{h}^{-1}\right)$ & $\begin{array}{c}\text { Estimated carbon stock } \\
\left(\mathrm{t} \mathrm{Ch}^{-1}\right)\end{array}$ & $\begin{array}{c}\text { Carbon loss for 22 years } \\
(\mathrm{t} \mathrm{C})\end{array}$ & $\begin{array}{c}\text { Carbon loss per year } \\
(\mathrm{t} \mathrm{Cyr})\end{array}$ \\
\hline Munishi et al. [5] & 35.8 & 17.9 & 97615.28 & 4437.06 \\
Malimbwi et al. [34] & 33.0 & 16.5 & 89980.57 & 4090.03 \\
Brown [35] & 36.0 & 18.0 & 98160.62 & 4461.85 \\
Chamshama et al. [36] & 38.09 & 19.05 & 103886.65 & 4722.12 \\
Average & $\mathbf{3 5 . 7 2}$ & $\mathbf{1 7 . 7 9}$ & $\mathbf{9 5 0 1 5 . 4 1}$ & $\mathbf{4 4 0 9 . 7 9}$ \\
\hline
\end{tabular}

decrease in woodlands from $32.66 \%$ (5453.37 ha) to $7.34 \%$ (1226.12 ha). The results also show that the grassland, cultivated land, bushland, and settlements increased substantially as shown in Figure 3. The results clearly indicate that the demand for land has increased from 1988 to 2010. This implies that agricultural activities increased at the expense of other land cover types mainly the woodlands. Mbonile et al. [47] and Noe [48] found that agricultural expansion had a significant effect on the natural vegetation. The continuous increase in cultivated land is also reflected in an increased area under settlements/bareland (Figure 3). Settlements expansion has an implication on the increase in population size as a result of the demand for more resources and area for cultivation.

As shown in Table 2, woodlands decreased at a rate of 192.15 ha per year assuming a linear decrease. It is possible that the decrease in woodland and increase in settlement cover are attributed to increased demand for land. This rapid decrease might be due to clear felling of trees for firewood, poles, timber, and increased settlements and agricultural activities (banana farms and subsistence farming). Bush fires were observed to be a serious problem in recent years. It is clear from Table 2 that the woodland decreased consistently over 22 years while cultivation increased at a rate of 90.89 ha/year (0.54\%/year). Timber harvesting business in the Miombo woodland has been encouraged by the existence of all weather roads from the area to other parts of the district and the neighboring countries [49]. The grassland decreased at a rate of $9.1 \mathrm{ha} / \mathrm{yr}(0.05 \% /$ year $)$. The settlement cover increased at a rate of $73.28 \mathrm{ha} /$ year $(0.44 \% /$ year $)$ over an average period of 22 year. The expansion of grassland, bushland, settlements, and cultivated areas reflects the LULC transformation in KFR. The increasing population as a result of refugees' influx and immigrants from other districts in Tanzania has had an impact on the natural resources in the study area. As Mbonile et al. [47] observe the major reason for in-migration is movement of people from their former residence to seek land for cultivation and habitation. Poor agricultural production in migrants' former villages is among the basic reasons for farmers to shift from their former land in their villages to new lands in other villages. On the other hand, population immigration has an increasing effect on the existing population of a given area and goes hand in hand with an increasing demand for natural resources including areas for settlements, cultivation, and other economic activities such as livestock keeping. According to Reid et al. [50], land conversion for agriculture in East Africa has outpaced the proportional human population growth in recent decades. Natural vegetation cover has given way not only to cropland but also to planted pasture [8]. As reported by Lyaruu [6] and Tiffen [7], the expansion of farms for cultivation in the world has transformed the land cover from natural vegetation to more agroecosystems. These changes have been fuelled by the growing demand for agricultural products that are important for improving food security and generating income, not only for the rural poor but also for the large-scale investors in the commercial farming sector.

The slight differences in carbon stocks estimated from different allometric models might be due to varying degree of exposure to human degradation and differences in the age of the tree species in the Miombo woodlands. The amount of carbon lost for the period of 22 years was estimated using four different allometric models developed in other Miombo 


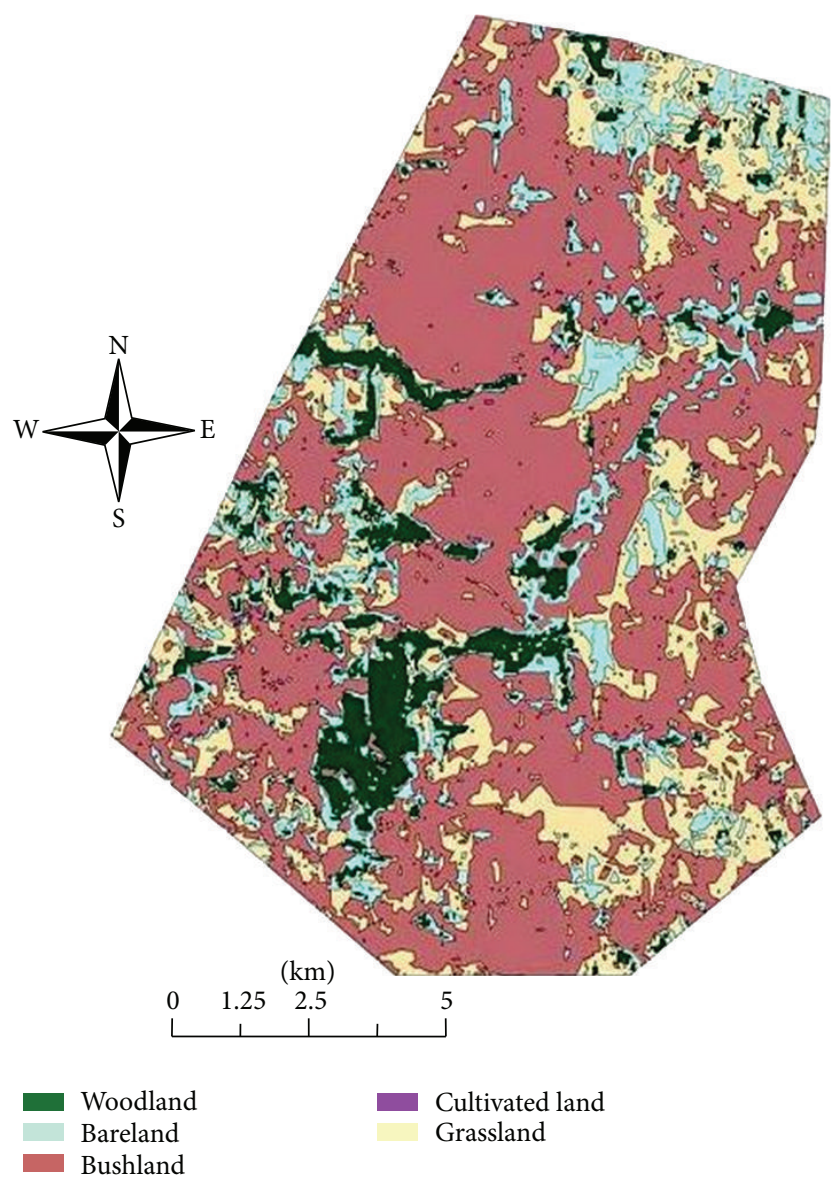

FIGURE 3: Land use and land cover map of image scene, 2010.

ecosystems. From these models, it was estimated that the woodlands in the KFR have lost an average of 95015.41 t C from 1988 to 2010 (Table 3). We estimated carbon loss in this study to be an average of $4409.79 \mathrm{t} \mathrm{Cyr}^{-1}$. The history of disturbance including fire, livestock grazing, logging/charcoal production, and shifting cultivation is likely to cause changes in the woody carbon stocks. The disturbance due to human utilization may have contributed to the lowering of the carbon stock in the KFR. As Brown [35] reports, forests that have been subjected to human disturbances tend to have lower biomass and less carbon storage than their storage potential. In another study, Munishi et al. [5] found that human destruction of tropical forests was estimated to contribute up to $17 \%$ of global carbon dioxide emissions, resulting into accelerated global warming. As reported by Williams et al. [28], clearances due to agriculture are estimated to reduce carbon stocks by $19 \mathrm{t} \mathrm{Ch}^{-1}$ in the Miombo woodlands of Mozambique.

The assessments of carbon stocks as influenced by different land use systems are among the important national REDD. Various studies show that different Miombo ecosystems have different biomass and carbon densities. For example, carbon stock estimates from Afromontane Rain Forests of the Eastern Arc Mountains were found to be between 252 and $581 \mathrm{t} \mathrm{Ch}^{-1}[25,51,52]$. In this study, the amount of carbon stocks stored was estimated to be $21,457.02$ tonnes in tree stem biomass based on the area ( $1226.12 \mathrm{ha})$ that is covered by woodlands. We estimated that an average of $17.79 \mathrm{t} \mathrm{Ch}^{-1}$ was stored in the Miombo woodlands based on the four different models (Table 3). This amount of carbon is similar to the amount of carbon density per hectare $\left(19.12 \mathrm{t} \mathrm{Ch}^{-1}\right)$ which was estimated by Munishi et al. [5] in the Miombo Woodlands of the Southern Highlands. However, the Eastern Miombo woodlands in Tanzania have been shown to have carbon storage potential of between 25 and $80 \mathrm{t} \mathrm{Ch}^{-1}$ [51].

\section{Conclusions}

The findings reveal that the study area had undergone notable changes in terms of LULC for the period of 1988-2010. Woodlands have decreased in the last 22 years, whereas bushland, grassland, cultivated land, and settlement areas increased linearly during the same period. The amounts of carbon stored and lost due to LULC changes in KFR were estimated to understand the relationship between the changes in land use and carbon dioxide emissions. Four allometric models were used to estimate carbon stored and lost for the last 22 years. Ecosystem carbon stocks lost averaged 95015.41 t C at the rate of $4409.79 \mathrm{t} \mathrm{Cyr}^{-1}$, while the current carbon stored is totaled 21457.02 tonnes in tree stem biomass. The history of disturbance (fire, elephants, logging/charcoal production, and shifting cultivation) is likely to influence changes in the woody carbon stocks. In this respect, managing the carbon stocks of KFR requires concerted efforts in reducing the human related degradation. The efforts to ensure proper management of the Miombo ecosystem can contribute to the creation of a considerable carbon sink and will ensure persistent potential for the Miombo woodlands to store carbon as sinks rather than emission sources thus contributing to the REDD process initiatives in Tanzania and globally.

\section{Conflict of Interests}

The authors declare that there is no conflict of interests regarding the publication of this paper.

\section{Acknowledgments}

The authors would like to express their appreciation to the anonymous reviewers for their constructive comments on the paper. They also thank the Kagera Region Forest and Beekeeping Division and Natural Resource Advisors for granting a permit to conduct this study in their areas of jurisdiction.

\section{References}

[1] G. Sileshi, F. K. Akinnifesi, O. C. Ajayi, S. Chakeredza, M. Kaonga, and P. W. Matakala, "Contribution of agroforestry to ecosystem services in the Miombo Eco-region of eastern and southern Africa," African Journal of Environmental Science and Technology, vol. 1, no. 4, pp. 68-80, 2007. 
[2] IGBP, The Terrestrial Biosphere and Global Change: Implications for Natural and Managed Ecosystems, International GeosphereBiosphere Programme, Stockholm, Sweden, 1997.

[3] G. C. Monela and J. M. Abdallah, "Principle socio-economic issues in utilization of Miombo Woodlands in Tanzania," Working Papers of the Finnish Forest Research Institute, vol. 50, pp. 115-122, 2007.

[4] S. Syampungani, P. W. Chirwa, F. K. Akinnifesi, G. Sileshi, and O. C. Ajayi, "The Miombo Woodlands at the cross roads: potential threats, sustainable livelihoods, policy gaps and challenges," Natural Resources Forum, vol. 33, no. 2, pp. 150-159, 2009.

[5] P. K. T. Munishi, S. Mringa, D. D. Shirima, and S. K. Linda, "The role of the Miombo Woodlands of the Southern Highlands of Tanzania as carbon sinks," Journal of Ecology and the Natural Environment, vol. 2, no. 12, pp. 261-269, 2010.

[6] H. V. Lyaruu, "Plant biodiversity component of the land use change, impacts and dynamics project, Mt. Kilimanjaro, Tanzania," LUCID Working Paper no. 40, ILRI, Nairobi, Kenya, 2002.

[7] M. Tiffen, "Transition in sub-Saharan Africa: agriculture, urbanization and income growth," World Development, vol. 31, no. 8, pp. 1343-1366, 2003.

[8] E. F. Lambin, H. J. Geist, and E. Lepers, "Dynamics of land-use and land-cover change in tropical regions," Annual Review of Environment and Resources, vol. 28, pp. 205-241, 2003.

[9] K. E. Trenberth, "Atmospheric moisture residence times and cycling: implications for rainfall rates and climate change," Climatic Change, vol. 39, no. 4, pp. 667-694, 1998.

[10] S. Manabe and R. J. Stouffer, "Coupled ocean-atmosphere model response to freshwater input: comparison to Younger Dryas Event," Paleoceanography, vol. 12, no. 2, pp. 321-336, 1997.

[11] H. J. Geist and E. F. Lambin, "Dynamic causal patterns of desertification," BioScience, vol. 54, no. 9, pp. 817-829, 2004.

[12] V. Vanacker, Geormophic response to human-induced environmental change in Tropical Mountains areas. The Austo Ecuatoriano as a case study [Ph.D. thesis], Katholic University of Leuven, 2002.

[13] L. Lundgren, "Studies of soils and vegetation development on fresh land slide scars in the Mgeta Valley, Western Uluguru Mountains, Tanzania," Geografiska Annular A, vol. 60, no. 4, pp. 91-126, 1978.

[14] W. B. Meyer and B. L. Turner, "Human population growth and global land-use/cover change," Annual Review of Ecology and Systematics, vol. 23, no. 1, pp. 39-61, 1992.

[15] H. Briassoulis, "Analysis of Land Use Change: Theoretical and Modeling Approach,” 2000, http://www.rri.wvu.edu/WebBook /Briassoulis/contents.htm.

[16] E. Hartemink, "Land use change in the tropics and its effect on soil fertility," in Proceedings of the 9th World Congress of Soil Science, Soil Solutions for a Changing World, Brisbane, Australia, August 2010.

[17] B. L. Turner II, R. E. Karsperson, W. B. Meyer et al., "Two types of global environmental change: definitional and spatialscale issues in their human dimensions," Global Environmental Change: Human and Policy Dimensions, vol. 1, no. 1, pp. 14-22, 1990.

[18] W. B. Meyer and B. L. Turner, "Land-use/land-cover change: challenges for geographers," GeoJournal, vol. 39, no. 3, pp. 237240, 1996.

[19] Q. Zhou, B. Li, and B. Sun, "Modeling spatial-temporal pattern of land use change using multi-temporal remotely sensed imagery," The International Archives of the Photogrammetry,
Remote Sensing and Spatial Information Sciences, vol. 37, pp. 729-734, 2008.

[20] J. J. Kashaigili, "Impacts of land-use and land-cover changes on flow regimes of the Usangu Wetland and the Great Ruaha River, Tanzania," Physics and Chemistry of the Earth, vol. 33, no. 8-13, pp. 640-647, 2008.

[21] A. M. Dewan and Y. Yamaguchi, "Using remote sensing and GIS to detect and monitor land use and land cover change in Dhaka Metropolitan of Bangladesh during 1960-2005," Environmental Monitoring and Assessment, vol. 150, no. 1-4, pp. 237-249, 2009.

[22] J. F. Richards, "Land transformation," in The Earth as Transformed by Human Action, pp. 163-178, Cambridge University Press, New York, NY, USA, 1990.

[23] M. A. Drummond and T. R. Loveland, "Land-use pressure and a transition to forest-cover loss in the Eastern United States," BioScience, vol. 60, no. 4, pp. 286-298, 2010.

[24] A. R. S. Kaoneka, Land use in the West Usambara Mountains: analysis of ecological and socio-economic aspects with special reference to forestry [Ph.D. thesis], Agricultural University of Norway, 1993.

[25] P. K. T. Munishi and T. H. Shear, "Carbon storage in afromontane rain forests of the Eastern Arc Mountains of Tanzania: their net contribution to atmospheric carbon," Journal of Tropical Forest Science, vol. 16, no. 1, pp. 78-93, 2004.

[26] E. N. Chidumayo, "Changes in Miombo Woodland structure under different land tenure and use systems in central Zambia," Journal of Biogeography, vol. 29, no. 12, pp. 1619-1626, 2002.

[27] S. Zingore, C. Manyame, P. Nyamugafata, and K. E. Giller, "Long-term changes in organic matter of woodland soils cleared for arable cropping in Zimbabwe," European Journal of Soil Science, vol. 56, no. 6, pp. 727-736, 2005.

[28] M. Williams, C. M. Ryan, R. M. Rees, E. Sambane, J. Fernando, and J. Grace, "Carbon sequestration and biodiversity of regrowing Miombo Woodlands in Mozambique," Forest Ecology and Management, vol. 254, no. 2, pp. 145-155, 2008.

[29] J. Chave, H. C. Muller-Landau, T. R. Baker, T. A. Easdale, H. Steege, and C. O. Webb, "Regional and phylogenetic variation of wood density across 2456 neotropical tree species," Ecological Applications, vol. 16, no. 6, pp. 2356-2367, 2006.

[30] K. T. Vashum and S. Jayakumar, "Methods to estimate aboveground biomass and carbon stock in natural forests. A review," Journal of Ecosystem \& Ecography, vol. 2, no. 116, pp. 1-7, 2012.

[31] C. M. Ryan, M. Williams, and J. Grace, "Above- and belowground carbon stocks in a Miombo Woodland landscape of Mozambique," Biotropica, vol. 43, no. 4, pp. 423-432, 2011.

[32] L. Touber and J. R. Kanani, "Landforms and soils of Bukoba district. Bukoba District Council, Bukoba District Rural Development Programme," Applied Soil Fertility Research Project, ARI Maruku, Bukoba, Tanzania, 1994.

[33] N. G. Nzunda, P. K. T. Munishi, J. J. Kashaigili, G. E. Soka, and J. F. Monjare, "Land use and vegetation cover dynamics in and around Kagoma Forest Reserve in Tanzania," Journal of Ecology and the Natural Environment, vol. 5, no. 8, pp. 206-216, 2013.

[34] R. E. Malimbwi, B. Solberg, and E. Luoga, "Estimation of biomass and volume in Miombo Woodland at Kitulangalo Forest Reserve, Tanzania," Journal of Tropical Forest Science, vol. 7, no. 2, pp. 230-242, 1994.

[35] S. Brown, "Estimating biomass and biomass change of tropical forests: a primer," UN FAO Forestry Paper 134, Food and Agriculture Organization of the United Nations, Rome, Italy, 1997. 
[36] S. A. O. Chamshama, A. G. Mugasha, and E. Zahabu, "Stand biomass and volume estimation for Miombo Woodlands at Kitulangalo, Morogoro, Tanzania," Southern African Forestry Journal, vol. 200, pp. 59-64, 2004.

[37] A. Yeh, A. Gar, and L. Xia, "Urban growth management in Pearl River Delta: an integrated remote sensing and GIS approach," ITC Journal, vol. 1, pp. 77-78, 1996.

[38] J. R. Jensen, Introductory Digital Image Processing: A Remote Sensing Perspective, Prentice Hall, New York, NY, USA, 2nd edition, 1996.

[39] H. Alphan, "Land-use change and urbanization of Adana, Turkey," Land Degradation \& Development, vol. 14, no. 6, pp. 575-586, 2003.

[40] J. Zhang and G. M. Foody, "Preface: spatial accuracy in remote sensing," International Journal of Remote Sensing, vol. 30, no. 20, pp. 5239-5242, 2009.

[41] D. Yuan and C. Elvidge, "NALC land cover change detection pilot study: Washington DC area experiments," Remote Sensing of Environment, vol. 66, no. 2, pp. 166-178, 1998.

[42] J. J. Kashaigili, Land covers dynamics and hydrological functioning of Wetlands in the Usangu Plains in Tanzania [Ph.D. thesis], Sokoine University of Agriculture, Morogoro, Tanzania, 2006.

[43] S. Brown, A. J. R. Gillespie, and A. E. Lugo, "Biomass estimation methods for tropical forests with applications to forest inventory data," Forest Science, vol. 35, no. 4, pp. 881-902, 1989.

[44] T. M. Basuki, P. E. van Laake, A. K. Skidmore, and Y. A. Hussin, "Allometric equations for estimating the above-ground biomass in tropical lowland Dipterocarp forests," Forest Ecology and Management, vol. 257, no. 8, pp. 1684-1694, 2009.

[45] P. N. Beets, M. O. Kimberley, G. R. Oliver, S. H. Pearce, J. D. Graham, and A. Brandon, "Allometric equations for estimating carbon stocks in Natural Forest in New Zealand," Forests, vol. 3, no. 3, pp. 818-839, 2012.

[46] J. Chave, "Neutral theory and community ecology," Ecology Letters, vol. 7, no. 3, pp. 241-253, 2004.

[47] J. M. Mbonile, B. S. Misana, and C. Sokoni, "Land use change and root causes on the Southern Slopes of Mount Kilimanjaro, Tanzania," LUCID Project Working Paper no. 25, International Livestock Research Institute, Nairobi, Kenya, 2003.

[48] C. Noe, "The dynamic of land use changes and their impacts on the Wildlife Corridor between Mount Kilimanjaro and Amboseli National Park, Tanzania," LUCID Report no. 31, International Livestock Research Institute, Nairobi, Kenya, 2003.

[49] G. Monela and B. Solsberg, "Deforestation rate and land use/land cover changes in rainforests of the Nguru Mountains, Tanzania," Faculty of Forestry Records no. 68, Sokoine University of Agriculture, Morogoro, Tanzania, 1998.

[50] R. S. Reid, L. N. Gachimbi, J. Worden et al., "Linkages between changes in land use, biodiversity and land degradation in the Loitokitok area of Kenya," LUCID Working Paper 49, International Livestock Research Institute, and United Nations Environment Programme/Division of Global Environment Facility Coordination, Nairobi, Kenya, 2004.

[51] ECCM, Establishing Mechanisms for Payments for Carbon Environomental Services in the Eastern Arc Mountains, Tanzania, The Edinburgh Centre for Carbon Management, 2007.

[52] P. K. T. Munishi and D. D. Shirima, "Measuring and Valuing the Carbon Stocks in Chome Nature Reserve, Eastern Arc Mountains," Tech. Rep., Eastern Arc Endowment Fund for Forest and Beekeeping Division, Dar es Salaam, Tanzania, 2010. 

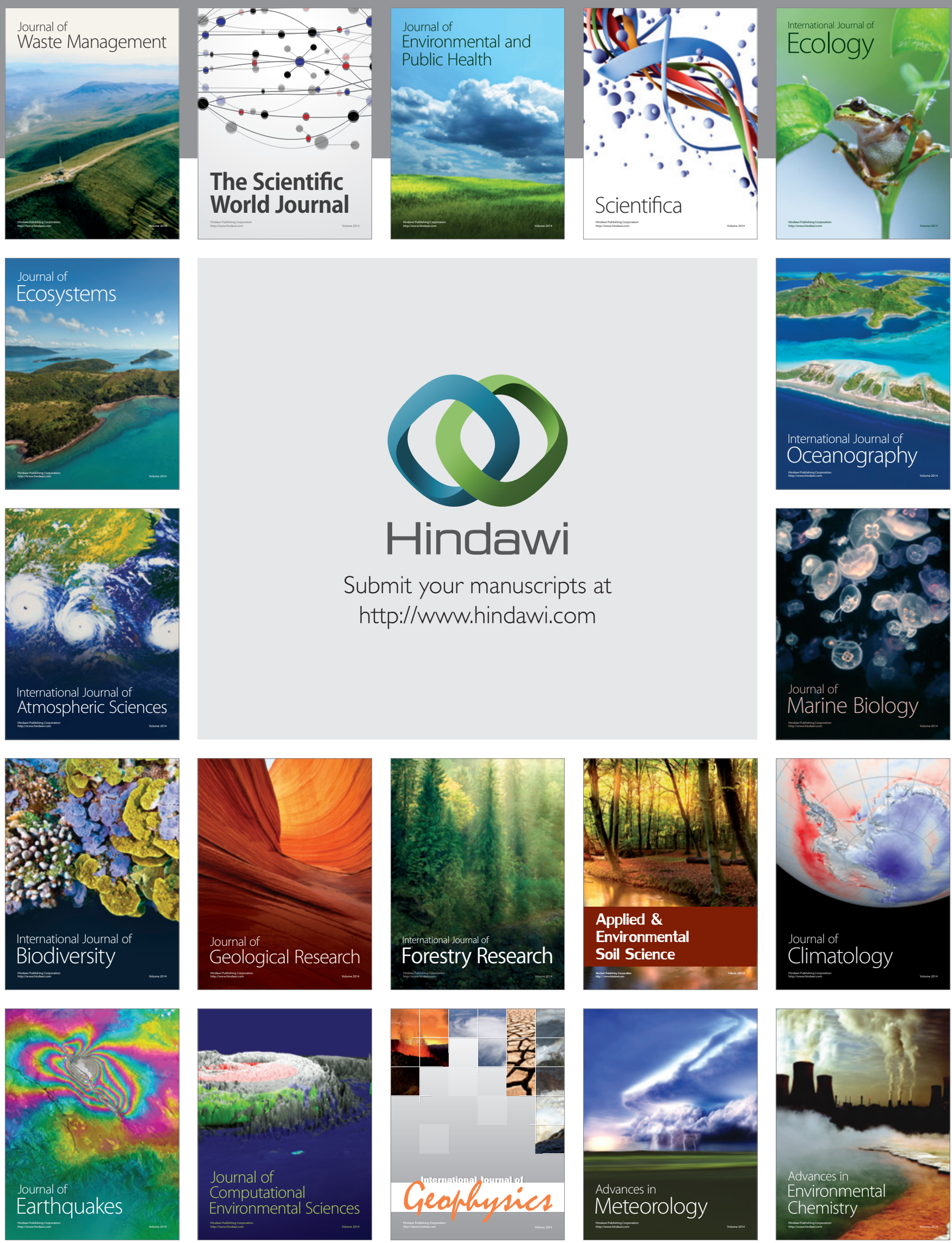